OPEN ACCESS

Citation: Rajesh R.R., Sakthidhasan P., Rajasekar C. (2021) Memecylon viswanathanii, a new species of Melastomataceae from Kalakkad-Mundanthurai Tiger Reserve (KMTR), India. Webbia. Journal of Plant Taxonomy and Geography 76(1): 71-76. doi: 10.36253/jopt10124

Received: December 24, 2020

Accepted: January 4, 2021

Published: April 27, 2021

Copyright: @2021 Rajesh R.R., Sakthidhasan P., Rajasekar C. This is an open access, peer-reviewed article published by Firenze University Press (http:// www.fupress.com/webbia) and distributed under the terms of the Creative Commons Attribution License, which permits unrestricted use, distribution, and reproduction in any medium, provided the original author and source are credited.

Data Availability Statement: All relevant data are within the paper and its Supporting Information files.

Competing Interests: The Author(s) declare(s) no conflict of interest.

Editor: Riccardo M. Baldini

ORCID

RR: https://orcid.org/0000-0002-44938995

PS: https://orcid.org/0000-0002-85102641

CR: https://orcid.org/0000-0002-91342828

\section{Memecylon viswanathanii, a new species of Melastomataceae from Kalakkad- Mundanthurai Tiger Reserve (KMTR), India}

\author{
Ramasamy Rajesh ${ }^{1}$, Perriasamy Sakthidhasan ${ }^{1}$, Chinnaiyan \\ RAJASEKAR ${ }^{2, *}$ \\ ${ }^{1}$ Department of Botany, Bharathidasan University, Tiruchirappalli 620024, Tamil Nadu, \\ India \\ ${ }^{2}$ Department of Botany, Alagappa University, Karaikudi 630003, Tamil Nadu, India \\ ${ }^{\star}$ E-mail for correspondence. E-mail: raraja2@gmail.com
}

\begin{abstract}
Memecylon viswanathanii R.Rajesh, P.Sakthidhasan \& C.Rajasekar, a new species of Melastomataceae, is described and illustrated from the Kalakkad-Mundanthurai Tiger Reserve (KMTR) in the southern Western Ghats of India. M. viswanathanii is close to M. parvifolium Thwaites and M. varians Thwaites but differs by several vegetative and floral characters. The species is assessed here as Critically endangered as per IUCN Red List.
\end{abstract}

Keywords: Southern Western Ghats, Critically endangered, M. parvifolium, M. varians.

\section{INTRODUCTION}

The genus Memecylon L. belonging to the family of Melastomataceae (The Angiosperm Phylogeny Group IV 2016) has 357 species (Renner et al. 2007 onwards) or around 379 (Michelangeli et al. 2020). It is reported that there are 55 species distributed in India wherein 22 species are endemic to the Western Ghats (Viswanathan and Manikandan 2001; Sivu et al. 2012, 2018; Prabhu and Murugan 2017; Das et al. 2018; Radh and Nampy 2019; Vadhyar et al. 2020). During an inventory in 2017, plant specimens were collected from the Kalakkad-Mundanthurai Tiger Reserve (KMTR) in the southern Western Ghats of Tamil Nadu in India. A critical assessment of pertinent literature (Clarke 1879; Gamble 1919; Bremer 1979, 1987; Viswanathan 2001) revealed that specimens of Memecylon collected from Vaniyangal podavu at an elevation of c. $1405 \mathrm{~m}$ MSL in the KMTR were hitherto unknown to science and turned out to be a new species. It is described here with a diagnosis, comparison with closely related species, detailed description, illustrations, phenology and other related details. 
Memecylon viswanathanii R.Rajesh, P.Sakthidhasan \& C.Rajasekar, sp. nov. (Figures 1 \& 2)

Type: INDIA, Tamil Nadu, Tenkasi district, Kadayam Forest Range, Vaniyangal podavu, $\pm 1405 \mathrm{~m}, 01$ March 2017, R. Rajesh, P. Sakthidhasan \& C. Rajasekar 1494 (holotype, $\mathrm{MH}$ !; isotypes, K!; Herbarium, Department of Botany, Bharathidasan University, Tiruchirappalli!).

\section{Diagnosis}

Closely related to $M$. parvifolium Thwaites and $M$. varians Thwaites by branches and greyish bark, coria-

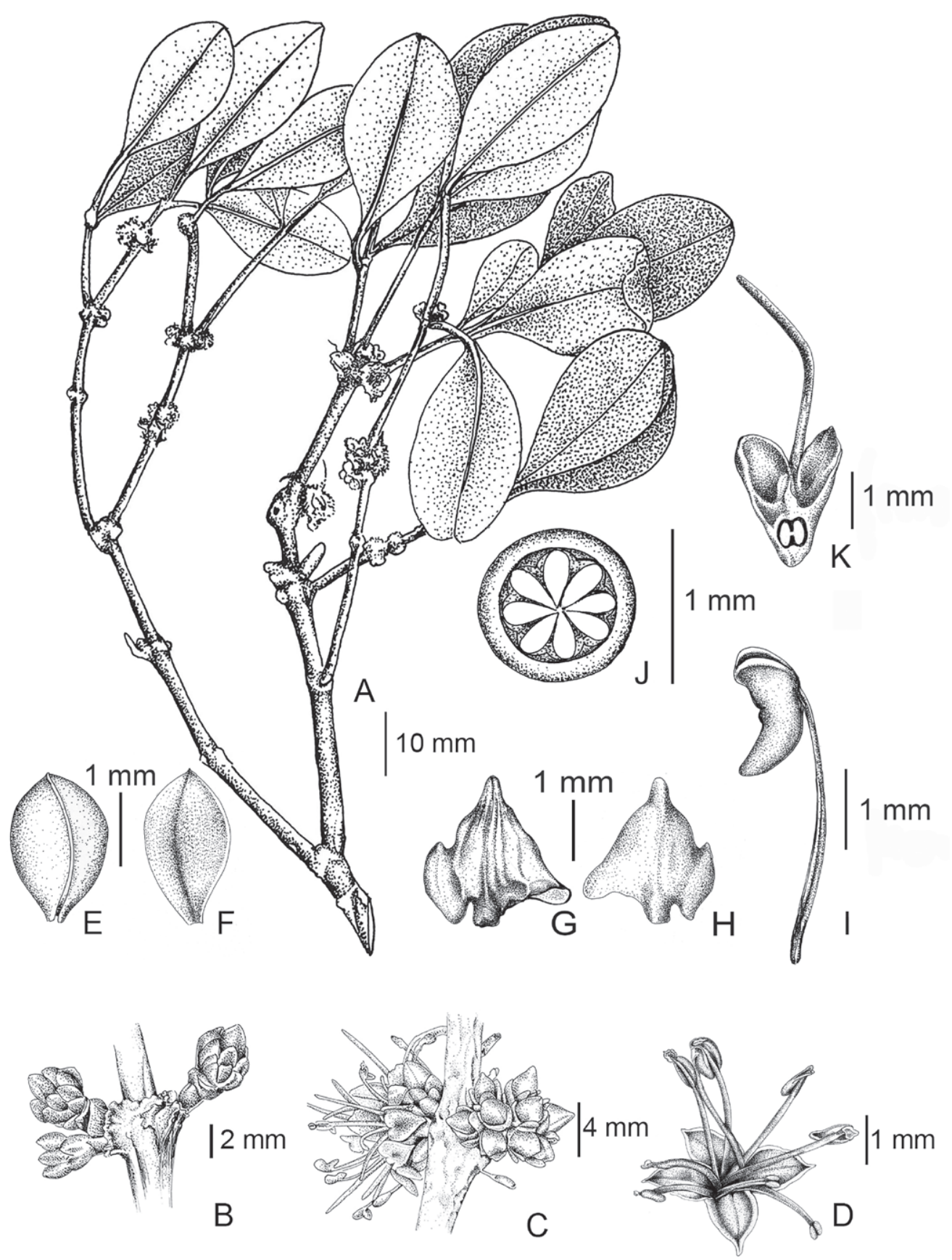

Figure 1. Memecylon viswanathanii R.Rajesh, P.Sakthidhasan \& C.Rajasekar, A, flowering branch; B, floral buds; C, opened and unopened flowers; D, flower; E, bracteole - abaxial surface; F, bracteole - adaxial surface; G, petal - abaxial view; H, petal - adaxial view; I, stamen; J, cross section of ovary; K, longitudinal section of ovary with two calyx lobes removed. 

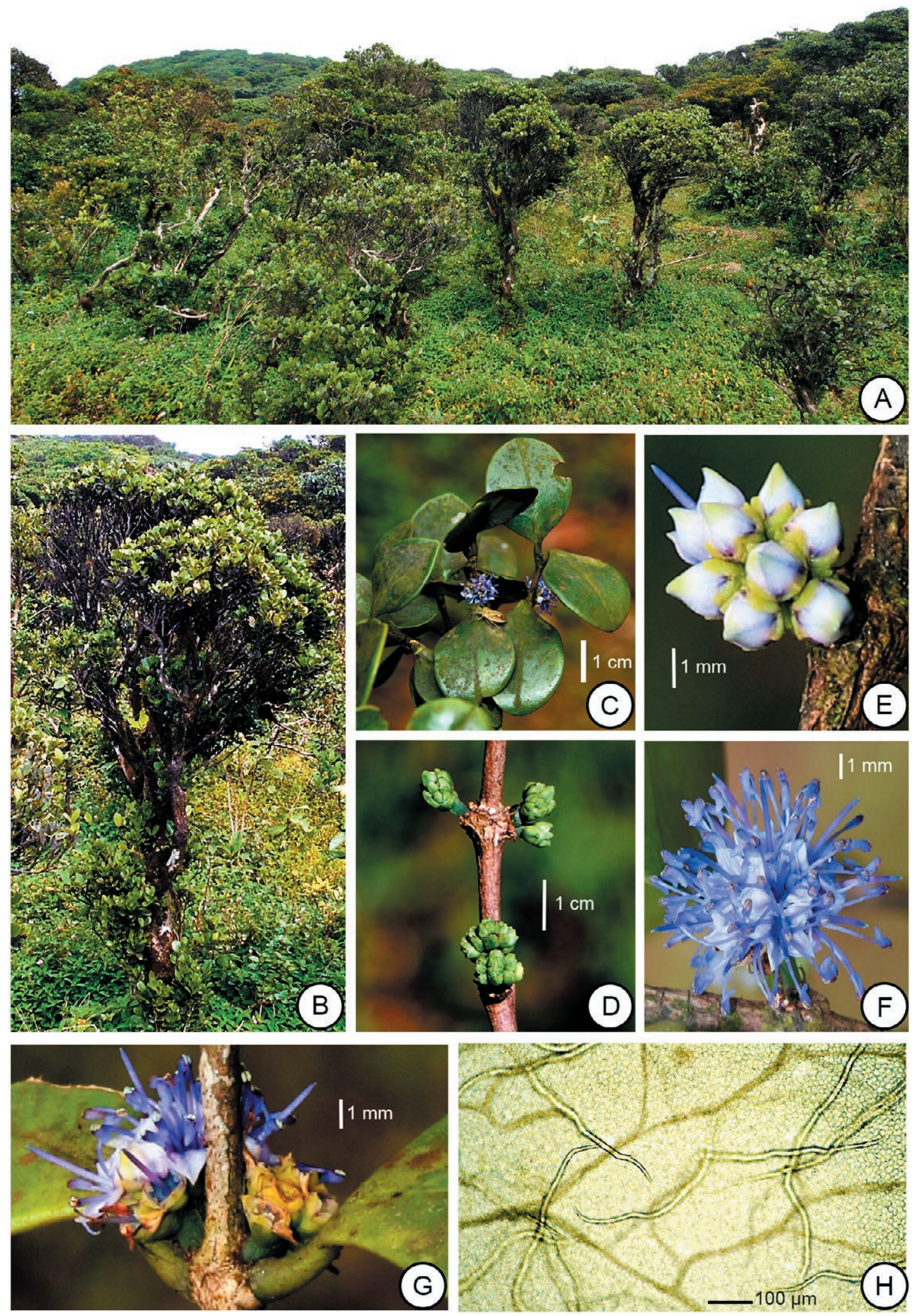

Figure 2. Memecylon viswanathani R.Rajesh, P.Sakthidhasan \& C.Rajasekar, sp. nov. A, trees in the southern Tropical wet evergreen forest; B, tree; C, flowering twig; D, immature floral buds with bracteoles; E, unopened flowers; F, fully opened flowers; G, flowers after fertilization; $\mathrm{H}$, a portion of cleared leaf showing narrowly filiform unbranched sclereids. 
Table 1. Comparison of M. viswanathanii with M. parvifolium and M. varians.

\begin{tabular}{|c|c|c|c|}
\hline Character & M. parvifolium & M. varians & M. viswanathanii \\
\hline Leaves & $\begin{array}{l}\text { elliptic to elliptic-obovate, cuneate at } \\
\text { base, obtuse to rounded or notched or } \\
\text { sometimes acute or occasionally shortly } \\
\text { and indistinctly caudate at apex, more } \\
\text { or less shining above, drying dark green, } \\
1-3.5 \times 0.5-2.5 \mathrm{~cm}\end{array}$ & $\begin{array}{l}\text { elliptic, cuneate at base, acute to } \\
\text { acuminate or caudate and subacute to } \\
\text { obtuse at the very apex, more or less dull } \\
\text { on both sides, drying yellowish green, } \\
\quad 3-9 \times 1.5-3 \mathrm{~cm}\end{array}$ & $\begin{array}{c}\text { broadly elliptic, obtuse or obtusely } \\
\text { cuneate at base, obtusely rounded, retuse } \\
1 \text { or emarginate at apex, more or less } \\
\text { shining above, drying yellowish green, } \\
1.5-3.2 \times 1-2 \mathrm{~cm}\end{array}$ \\
\hline Leaf margins & often revolute & not revolute & revolute \\
\hline Petiole length & $1-2 \mathrm{~mm}$ & $2-3 \mathrm{~mm}$ & $3-4 \mathrm{~mm}$ \\
\hline Foliar sclereids & $\begin{array}{l}\text { Aggregated to sclerocysts around the } \\
\text { veins or vein-endings }\end{array}$ & $\begin{array}{c}\text { irregularly elongated to filiform, often } \\
\text { branched }\end{array}$ & narrowly filiform, unbranched \\
\hline Peduncle length & $0 \mathrm{~mm}$ & $1-6 \mathrm{~mm}$ & $2-4 \mathrm{~mm}$ \\
\hline Pedicels & $\begin{array}{c}\text { shorter than or about the same length as } \\
\text { the calyx }\end{array}$ & 0 or shorter than the calyx & 0 \\
\hline Receptacle & smooth & \pm papillose & warty \\
\hline Calyx & smooth or shallowly striate inside & smooth or shallowly striate inside & smooth inside \\
\hline Petals & white & blue & whitish pale blue \\
\hline Disc & smooth or shallowly striate & smooth or shallowly striate & smooth \\
\hline Connectives & without a gland & without or with a gland & with a gland \\
\hline
\end{tabular}

ceous leaves with indistinct intramarginal and lateral veins and inflorescence in axillary fascicles but differing in having broadly elliptic leaves with petioles up to $4 \mathrm{~mm}$ long, narrowly unbranched filiform sclereids, absence of pedicels and whitish pale blue flowers from $M$. parvifolium and $M$. varians, up to $4 \mathrm{~mm}$ long peduncles, warty receptacle and connective bearing gland from $M$. parvifolium and smaller leaves with revolute margin and shorter peduncles from $M$. varians (Table 1).

\section{Description}

Trees, c. $4 \mathrm{~m}$ high; branches and branchlets subquadrangular; bark ashy grey mixed with brown; nodes annular; internodes abbreviated, $0.4-2.5 \times 0.2-0.6 \mathrm{~cm}$. Leaves decussate - opposite, coriaceous, broadly elliptic, obtuse or obtusely cuneate at base, revolute at margin, obtusely rounded, retuse or emarginate at apex, 1.5-3.2 $\times 1.0-2.0 \mathrm{~cm}$, green with pale yellow above, yellowish green beneath when dry, yellow with age, glabrous; midrib prominent, sulcate adaxially, raised abaxially; intramarginal and lateral veins indistinct, rarely basal 2 to 3 pairs faintly distinct up to half way adaxially; petioles grooved adaxially, 3-4 × 0.4-0.5 mm. Foliar sclereids monomorphic, narrowly filiform, unbranched. Flowers in axillary fascicles, either at leaf axils or leafless nodes, 6-12 pairs in each fascicle, either at one side or both sides of a node, 4-merous, bisexual with an epigynous disc, $1-1.5 \times 1.5-2 \mathrm{~mm}$; fascicles each c. $8 \mathrm{~mm}$ across; open flowers including hypanthium and expanded petals 5-6 $\times 2.5-3 \mathrm{~mm}$; bracteoles many, in clusters, at the base of the flowers, elliptic, green, denticulate at margin, c. $0.5 \times 1 \mathrm{~mm}$; peduncles $2-4 \times 1-2 \mathrm{~mm}$; pedicels 0 . Receptacles pale blue, campanulate-cyathiform, prolonged above ovary, continuous with calyx, warty outside. Calyx shallowly 4-lobed; cup warty outside, pale blue outside, c. $1 \times 1.2 \mathrm{~mm}$; lobes deltoid or triangular in outline, warty outside, smooth inside, pale blue with pink tinge outside, c. $0.5 \times 1 \mathrm{~mm}$. Petals 4 , imbricate in bud, whitish pale blue, orbicular, deltoid in outline, slightly undulate at margin, subacuminate at apex, 2.5-3 $\times 1.5-2 \mathrm{~mm}$. Disc dark blue, smooth. Stamens 8, equal; filaments bluish white, whitish dark blue, incurved in bud, straight, $4-5 \times$ c. $0.2 \mathrm{~mm}$; anthers dithecous, pale brown, opening by slits, c. $0.2 \times 0.3 \mathrm{~mm}$; connectives blue, attached ventrally with anthers, nearly axe-shaped, obtuse - rounded at base, $0.8-1 \times 0.2-0.3 \mathrm{~mm}$; gland disc-shaped, at dorsal middle of the surface, pinkish brown. Ovary 1-celled; ovules 8, attached to central placenta; style blue to pinkish blue after fertilization, $4-5 \times$ 0.2-0.3 mm. Fruit not collected.

\section{Etymology}

The specific epithet is in honor of Prof. M.B. Viswanathan, Department of Botany, Bharathidasan University, for his contribution to the field of Plant Taxonomy in India.

\section{Phenology}

Flowering: February to April. 


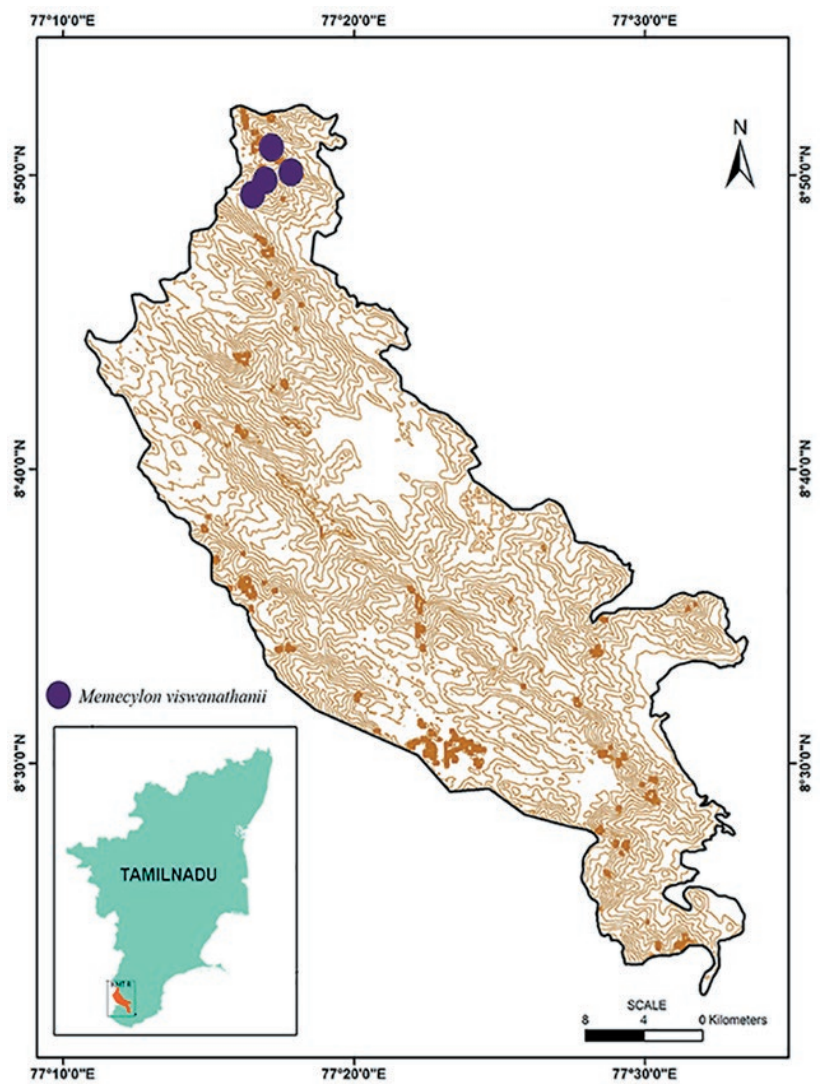

Figure 3. Distribution of Memecylon viswanathanii R.Rajesh, P.Sakthidhasan \& C.Rajasekar (purple circles) in the KalakkadMundanthurai Tiger Reserve (KMTR).

\section{Distribution}

Endemic to the Kadayam Forest Range of the Tenkasi district in the KMTR of India.

\section{Habitat}

Southern Tropical wet evergreen forest with trees of Mappia nimmoniana (J.Graham) Byng \& Stull and Monosis travancorica (Hook.f.) H.Rob. \& Skvarla, shrubs of Psychotria bisulcata Wight \& Arn., undershrubs of Hedyotis ramarowii (Gamble) R.S.Rao \& Hemadri and herbs of Acmella paniculata (Wall. ex DC.) R.K.Jansen, Eriocaulon ensiforme C.E.C.Fischer, Impatiens tanyae R.Kr.Singh, Arigela \& Kabeer, Peperomia dindygulensis Miq., Rostellularia simplex Wight, Sonerila travancorica Bedd., Utricularia reticulata $\mathrm{Sm}$. and Zenkeria sebastinei A.N.Henry \& Chandrab. Populations are restricted to elevations above $1400 \mathrm{~m}$ in the northern part of the KMTR.

\section{Conservation Status}

This species comprises 252 mature individuals in 4 populations. We recommend a conservation status of critically endangered (CR) based on IUCN Red List Guidelines and Criteria (IUCN, 2019), on the basis of B1. Extent of occurrence (EOO) $-6.51 \mathrm{~km}^{2}$ and $\mathrm{B} 2$ and Area of occupancy (AOO) $-0.203 \mathrm{~km}^{2}$ (Figure 3).

\section{Taxonomic affinity}

Comparison of $M$. parvifolium, $M$. varians and $M$. viswanathanii is given in Table 1.

\section{ACKNOWLEDGEMENTS}

The first author is grateful for the award of Junior and Senior Research Fellowship of the DST-PURSE (Bharathidasan University Ref. No. 41891/E8/2010 dt. 06.02.2012) and Project Fellow of the UGC-SAP DRSII (Bharathidasan University Ref. No. 43278/P2/2010 dt. 16.05.2019). The authors sincerely thank Dr. G.V.S. Murthy, former Deputy Director of $\mathrm{MH}$, for permission to consult specimens, Dr. V.S. Sampath Kumar, Scientist 'E', for literature help, Mr. R. Suresh, Artist, for the illustration and Dr. Fabián A. Michelangeli, New York Botanical Garden USA for meticulous review of the manuscript.

\section{REFERENCES}

Bremer K. 1979. Taxonomy of Memecylon (Melastomataceae) in Ceylon. Opera Botanica. 50: 1-32.

Bremer K. 1987. Memecylon. In: Dassanayakae MD, Fosberg FR, editors. A Revised Handbook to the Flora of Ceylon. Vol VI. New Delhi: Amerind Publishing; p. 206-238.

Clarke CB. 1879. Memecylon. In: Hooker JD, editor. The Flora of British India. Vol. 2. London: Reeve \& Co.; p. 553-565.

Das MD, Giri GS, Pramanik A, Maity D. 2018. Taxonomic status of Memecylon petiolatum Trimen ex Alston (Melastomataceae) and its extension of distribution to India. Feddes Repert. 129(1): 51-57.

Gamble JS. 1919. Flora of the Presidency of Madras. Vol. 1. London: Adlard \& Son; p. 500-505.

IUCN Standards and Petitions Committee. 2019. Guidelines for Using the IUCN Red List Categories and Criteria, Version 14, Prepared by the Standards and Petitions Committee. Available from http://www. iucnredlist.org/documents/RedListGuidelines.pdf (accessed 01 June 2020).

Michelangeli F, Almeda F, Goldenberg R, Penneys D. 2020. A guide to curating New World Melastomataceae collections with a Linear Generic Sequence to World- 
Wide Melastomataceae. Preprints 2020. 2020100203. https://doi.org/10.20944/preprints202010.0203.v1

Prabhu S, Murugan C. 2017. A new species of Memecylon (Melastomataceae) from the Western Ghats, India. Indian J Forest. 40(1): 69-71.

Radh SS, Nampy S. 2019. Memecylon idukkianum, a new species of Melastomataceae from Kerala, India. Kew Bull. 74(1): 6. https://doi.org/10.1007/s12225-0199800-y

Renner SS, Triebel D, Almeda F, Stone D, Ulloa C, Michelangeli FA, Goldenberg R, Mendoza H. 2007 onwards. MEL names: a database with names of Melastomataceae. Available from http://www.melastomataceae.net/MELnames/ (accessed 16 December 2020).

Sivu AR, Ratheesh Narayanan MR, Pradeep NS, Kumar NA, Pandurangan AG. 2012. Memecylon wayanadense (Melastomataceae), a new species from the Western Ghats, India. Edinb J Bot. 69(3): 371-378. https://doi.org/10.1017/S0960428612000212

Sivu AR, Pradeep NS, Pandurangan AG, Narayanan MKR. 2018. A new species of Memecylon (Melastomataceae) from Western Ghats, India. Taiwania. 63(2): 106-110.

The Angiosperm Phylogeny Group, Chase MW, Christenhusz MJM, Fay MF, Byng JW, Judd WS, Soltis DE, Mabberley DJ, Sennikov AN, Soltis PS, Stevens PF. 2016. An update of the Angiosperm Phylogeny Group classification for the orders and families of flowering plants: APG IV. Bot J Linn Soc. 181: 1-20.

Vadhyar RG, Benjamin JHF, Sujana KA. 2020. Memecylon nervosum (Melastomataceae), A new species from South India. Edinb J Bot. 77: 403-411.

Viswanathan MB. 2001. Two new species in Memecylon (Melastomataceae) from India. Nordic J Bot. 21(3): 253-258.

Viswanathan MB, Manikandan U. 2001. A new species, Memecylon mundanthuraianum, of Melastomataceae from India. Nordic J Bot. 21(3): 259-262. 